Société d'histoire de la révolution de 1848 et des

révolutions du XIXe siècle

$5 \mid 1989$

Histoires de centenaires, ou le devenir des révolutions

\title{
Les commémorations maçonniques des révolutions du XIXe siècle en France
}

\section{André Combes}

\section{OpenEdition}

\section{Journals}

Electronic version

URL: http://journals.openedition.org/rh19/43

DOI: $10.4000 /$ rh 19.43

ISSN: $1777-5329$

\section{Publisher}

La Société de 1848

\section{Printed version}

Date of publication: 1 June 1989

ISSN: 1265-1354

\section{Electronic reference}

André Combes, «Les commémorations maçonniques des révolutions du XIXe siècle en France », Revue d'histoire du XIXe siècle [Online], 5 | 1989, Online since 09 September 2008, connection on 01 May 2019. URL : http://journals.openedition.org/rh19/43; DOI : 10.4000/rh19.43

This text was automatically generated on 1 May 2019.

Tous droits réservés 


\section{Les commémorations maçonniques des révolutions du XIXe siècle en} France

André Combes

\section{ABSTRACTS}

No abstract available by now

Pas de résumé disponible actuellement

INDEX

Mots-clés: Commémoration, Sociétés secrètes, Révolutions 